\title{
ANTROPOLOGI ISLAM DI INDONESIA
}

\author{
Muhamad Taufik Hidayat \\ STIT Brebes \\ Jl. Yos Sudarso No. 36 Brebes52211 \\ E-mail: muhtahida@yahoo.com \\ HP. +62-8121495767
}

Abstract: This article studies the importance of religion understanding which is reflected in their culture. The main position of people in Islam indicates that we have to understand Allah. Anthropologists learn the culture and society to understand the meaning and the core of religion and its role in man's life. The cultural concept is basically a tool to see, to learn and to understand the religion which in its society.

Abstrak: Tulisan ini membahas tentang pemahaman agama tidak akan lengkap tanpa memahami realitas manusia yang tercermin dalam budayanya. Posisi penting manusia dalam Islam - seperti digambarkan dalam proses penciptaannya yang ruhnya merupakan tiupan dari ruh Tuhan-memberikan indikasi bahwa manusia menempati posisi penting dalam mengetahui Tuhan. Para ahli antropologi, yang perhatian utamanya adalah kebudayaan dan masyarakat, telah mencoba untuk melihat dan mengkaji agama sesuai dengan perspektif antropologi. Kajian-kajian tersebut dilakukan dalam upaya memahami makna dan hakikat agama di dalam dan bagi kehidupan manusia. Konsep kebudayaan pada dasarnya dapat digunakan sebagai alat untuk melihat, mengkaji dan memahami agama yang hidup dalam masyarakat.

Kata Kunci: Manusia, Agama, Kebudayaan, Antropologi, Tuhan.

\section{A. Pendahuluan}

Para ahli antropologi, yang perhatian utamanya adalah kebudayaan dan masyarakat, telah mencoba untuk melihat dan mengkaji agama sesuai dengan perspektif antropologi. Kajian-kajian tersebut dilakukan dalam upaya memahami makna dan hakikat agama di dalam dan bagi kehidupan manusia. Di Indonesia, kajian-kajian empirik tentang keislaman tersebut antara lain telah dilakukan oleh Geertz (1963, 1971), Suparlan (1995), Woodward (1989), Pra- 
nowo (2009), dan Muhaimin AG (2001). Pendekatan yang digunakan oleh para ahli antropologi dalam pengkajian agama adalah pendekatan kebudayaan yang dilakukan secara eksplisit atau pun secara implisit, yaitu melihat agama sebagai kebudayaan dan melihat agama sebagai bagian yang tidak terpisahkan-dan bahkan menjadi inti-dari kebudayaan yang terwujud dan mengejawantah sebagai nilai budaya dari kebudayaan masyarakat yang bersangkutan (Suparlan, 1998: 110).

Apabila agama dilihat dan diperlakukan sebagai kebudayaan, yaitu sebagai nilai-nilai budaya dari masyarakat yang dikaji, agama dilihat dan diperlakukan sebagai pengetahuan dan keyakinan-keyakinan yang dipunyai oleh sebuah masyarakat. Pengetahuan dan keyakinan tersebut menjadi patokan-patokan sakral yang berlaku di dalam hampir semua kegiatan pemenuhan kebutuhan manusia. Oleh karena itu, tindakan-tindakan memenuhi kebutuhan manusia itu dapat menjadi beradab, penuh dengan ciri-ciri kemanusiaan, yang berbeda dengan pemenuhan kebutuhan-kebutuhan biologi dan sosial hewan.

Pada waktu agama dilihat dan diperlakukan sebagai kebudayaan, maka yang terlihat adalah agama sebagai keyakinan yang ada dan hidup dalam masyarakat manusia, dan bukannya agama yang terwujud sebagai petunjukpetunjuk dan larangan-larangan serta perintah-perintah Tuhan yang ada dalam al-Qur'an dan hadis Nabi. Jika agama Islam yang tertuang sebagai teks suci dalam al-Qur'an dan hadis itu bersifat universal, keyakinan keagamaan yang hidup dalam masyarakat it u bersifat lokal, yaitu lokal sesuai dengan kondisi masyarakat, sejarah, lingkungan hidup, dan kebudayaannya.

Untuk dapat menjadi pengetahuan dan keyakinan-keyakinan dari masyarakat yang bersangkutan, maka agama (Islam) harus melakukan berbagai proses perjuangan dalam upaya meniadakan nilai-nilai budaya yang bertentangan dengan keyakinan hakiki dari agama tersebut. Islam juga melakukan berbagai penyesuaian nilai-nilai hakiki yang ada dalam keyakinan agama tersebut dengan nilai-nilai budaya dari masyarakat sehingga dapat diterima dan diyakini kebenarannya. Dalam keadaan demikian itulah, Islam yang diterima oleh sebuah masyarakat menjadi bersifat lokal. Tulisan ini hendak mengkaji tentang penerimaan masyarakat terhadap agama yang mampu merasuk pada sistem nilai sehingga bisa bertransformasi dalam kehidupan.

\section{B. Antropologi dan Kajian Agama}

Pendekat an antropologi dalam kajian agama berangkat dari preposisi bahwa agama tidak berdiri sendiri; ia selalu berhubungan erat dengan pemeluknya. Setiap pemeluk agama memiliki sistem budaya dan kultur masing-masing. 
Menurut Gellner, agama tidak bisa dilihat sebagai sistem yang otonom yang tidak terpengaruh oleh praktik-praktik sosial lainnya (Galner, 2009: 34).

Fenomena agama adalah fenomena universal manusia. Selama ini, belum ada laporan penelitian dan kajian yang menyatakan bahwa ada sebuah masyarakat yang tidak mempunyai konsep tentang agama. Walaupun peristiwa perubahan sosial telah mengubah orientasi dan makna agama. Hal itu tidak berhasil meniadakan eksistensi agama dalam masyarakat sehingga kajian tentang agama selalu akan terus berkembang dan menjadi kajian yang penting. Oleh karena sifat universalitas agama dalam masyarakat, maka kajian tentang masyarakat tidak akan lengkap tanpa melihat agama sebagai salah satu faktornya.

Pernyataan bahwa agama adalah suatu fenomena abadi juga memberikan gambaran bahwa keberadaan agama tidak lepas dari pengaruh realitas di sekelilingnya. Kerapkali praktik-praktik keagamaan pada suat u masyarakat dikembangkan dari doktrin ajaran agama, dan kemudian disesuaikan dengan lingkungan budaya. Pertemuan antara doktrin agama dan realitas budaya terlihat sangat jelas dalam praktik ritual agama. Dalam Islam, misalnya perayaan Idul Fitri di Indonesia yang dirayakan dengan tradisi sungkeman-bersilaturahmi kepada yang lebih tua - adalah sebuah bukti dari keterpautan antara nilai agama dan kebudayaan (Rakhmat, 2004: 181). Pertautan antara agama dan realitas budaya dimungkinkan terjadi karena agama tidak berada dalam realitas yang vakum - selalu orisinal. Mengingkari keterpautan agama dengan realitas budaya berarti mengingkari realitas agama sendiri yang selalu berhubungan dengan manusia, yang pasti dilingkari oleh budayanya.

Salah satu hal yang menarik dalam ajaran Islam adalah bahwa ia tidak pernah datang dalam suatu kebudayaan yang kosong. Islam selalu diberi warna oleh berbagai celupan dan budaya lokal. Ajaran Islam yang dipraktikkan di Indonesia, seperti halal bi halal adalah khazanah budaya lokal Indonesia, di samping ada juga hal-hal yang sama di seluruh dunia. Di negara-negara lain tidak ada acara seperti halal bi halal. Yang demikian adalah budaya lokal guna mewarnai ajaran dan memberikan mozaik budaya Islam. Idul Fitri adalah nilai ajaran Islam yang universal. Lebaran adalah nilai lokal yang diberikan kepada Idul Fitri. Oleh karena itu, tidak perlu mencari dalil dari al-Qur'an dan Sunah Nabi untuk acara lebaran tersebut. Warna-warni lokal yang diberikan oleh bangsa Indonesia, seperti halal bi halal dan lebaran harus dipertahankan sebagai kontribusi umat Islam Indonesia untuk memperkaya khazanah budaya Islam, dan bukan dibasmi atau dibid'ahkan. Jika bangsa Indonesia ingin melanjutkan 
Sunah Nabi, maka di antara yang harus dilakukan adalah menyebarkan ajaran Islam dengan berpijak pada akar budaya yang ada.

Kenyataan yang demikian itu juga memberikan arti bahwa perkembangan agama dalam sebuah masyarakat — dalam wacana dan praktis sosialnyamenunjukkan adanya unsur konstruksi manusia. Walaupun tentu pernyataan ini tidak berarti bahwa agama semata-mata merupakan ciptaan manusia, melainkan hubungan yang tidak bisa dielakkan antara konstruksi Tuhanseperti yang tercermin dalam kitab-kitab suci-dan konstruksi manusiaterjemahan dan interpretasi dari nilai-nilai suci agama yang direpresentasikan pada praktik ritual keagamaan. Pada saat manusia melakukan interpretasi terhadap ajaran agama, maka mereka dipengaruhi oleh lingkungan budayaprimordial-yang telah melekat di dalam dirinya. Hal ini dapat menjelaskan mengapa interpretasi terhadap ajaran agama berbeda dari satu masyarakat ke masyarakat lainnya. Kajian komparatif Islam di Indonesia dan Maroko yang dilakukan oleh Geertz, misalnya, membuktikan adanya pengaruh budaya dalam memahami Islam. Di Indonesia, Islam menjelma menjadi suatu agama yang sinkretik, sementara di Maroko, Islam mempunyai sifat yang agresif dan penuh gairah. Perbedaan manifestasi agama itu menunjukkan betapa realitas agama sangat dipengaruhi oleh lingkungan budaya (Geertz, 1982: 19-24).

Perdebatan dan perselisihan dalam masyarakat Islam sesungguhnya adalah perbedaan dalam masalah interpretasi, dan merupakan gambaran dari pencarian bentuk pengamalan agama yang sesuai dengan konteks budaya dan sosial. Misalnya dalam menilai persoalan-persoalan tentang hubungan politik dan agama yang dikaitkan dengan persoalan kekuasaan dan suksesi kepemimpinan, adalah persoalan keseharian manusia. Dalam hal ini, masalah interpretasi agama dan penggunaan simbol-simbol agama untuk kepentingan kehidupan manusia. Tentu saja, peran dan makna agama akan beragam sesuai dengan keragaman masalah sosialnya.

Antropologi, sebagai sebuah ilmu yang mempelajari manusia, menjadi sangat penting untuk memahami agama. Antropologi mempelajari tentang manusia dan segala perilaku mereka untuk dapat memahami perbedaan kebudayaan manusia. Dibekali dengan pendekatan yang holistik dan komitmen antropologi terhadap pemahaman tentang manusia, maka sesungguhnya antropologi merupakan ilmu yang penting untuk mempelajari agama dan interaksi sosialnya dengan berbagai budaya. Posisi penting manusia dalam Islam juga mengindikasikan bahwa sesungguhnya persoalan utama dalam memahami agama Islam adalah memahami manusia. Persoalan-persoalan yang dialami manusia adalah sesungguhnya persoalan agama yang sebenarnya. Pergumulan 
dalam kehidupan kemanusiaan pada dasarnya adalah pergumulan keagamaannya.

Dengan demikian, memahami Islam yang telah berproses dalam sejarah dan budaya tidak akan lengkap tanpa memahami manusia. Realitas keagamaan sesungguhnya adalah realitas kemanusiaan yang mengejawantah dalam dunia nyata. Terlebih dari itu, makna hakiki dari keberagamaan adalah terletak pada interpretasi dan pengamalan agama. Oleh karena itu, antropologi sangat diperlukan untuk memahami Islam sebagai alat untuk memahami realitas kemanusiaan dan memahami Islam yang telah dipraktikkan, yang menjadi gambaran sesungguhnya dari keberagamaan manusia.

Di Indonesia, usaha para antropolog untuk memahami hubungan agama dan sosial telah banyak dilakukan. Barangkali, karya Geertz, The Religion of Java, yang ditulis pada awal 1960-an menjadi karya yang populer sekaligus penting bagi diskusi tentang agama di Indonesia, khususnya di Jawa. Pandangan Geertz yang mengungkapkan tentang adanya trikotomi-abangan, santri, dan priyayi - di dalam masyarakat Jawa, ternyata telah memengaruhi banyak orang dalam melakukan analisis, baik tentang hubungan antara agama dan budaya, ataupun hubungan antara agama dan politik. Dalam diskursus interaksi antara agama—khususnya Islam — dan budaya di Jawa, pandangan Geertz telah mengilhami banyak orang untuk melihat lebih mendalam tentang interrelasi antara keduanya. Keterpengaruhan itu bisa dilihat dari beberapa pandangan yang mencoba menerapkan kerangka berpikir Geertz ataupun mereka yang ingin melakukan kritik terhadap wacana Geertz.

Pandangan trikotomi Geertz tentang pengelompokan masyarakat Jawa berdasar religio-kulturalnya berpengaruh terhadap cara pandang para ahli dalam melihat hubungan agama dan politik. Penjelasan Geertz tentang adanya pengelompokan masyarakat Jawa ke dalam kelompok sosial politik didasarkan pada orientasi ideologi keagamaan. Walaupun Geertz mengelompokkan masyarakat Jawa ke dalam tiga kelompok, ketika dihadapkan pada realitas politik, yang jelas-jelas menunjukkan oposisinya adalah kelompok abangan dan santri. Pernyataan Geertz bahwa abangan adalah kelompok masyarakat yang berbasis pertanian, dan santri yang berbasis pada perdagangan dan priyayi yang dominan di dalam birokrasi, ternyata mempunyai afiliasi politik yang berbeda. Kaum abangan lebih dekat dengan partai politik dengan isu-isu kerakyatan, priyayi dengan partai nasionalis, dan kaum santri memilih partai-partai yang memberikan perhatian besar terhadap masalah keagamaan.

Antropologi yang melihat langsung secara detil hubungan antara agama dan masarakat dalam tataran grassroot memberikan informasi yang sebenarnya 
yang terjadi dalam masyarakat. Melihat agama dalam masyarakat, bagi antropologi adalah melihat agama dipraktikkan, diinterpretasi, dan diyakini oleh penganutnya. Jadi, pembahasan tentang hubungan agama dan budaya sangat penting untuk melihat agama yang dipraktikkan.

Kepentingan untuk melihat agama dalam masyarakat juga sangat penting jika dikaitkan dengan wacana posmodernisme yang berkembang belakangan ini. Menurut Ma'ruf (2010:1-5), persoalan kajian antropologi bagi kajian Islam dapat dilihat relevansinya dengan melihat dua hal. Pertama, penjelasan antropologi sangat berguna untuk membantu mempelajari agama secara empirik. Artinya, kajian agama harus diarahkan pada pemahaman aspek-aspek social context yang melingkupi agama. Kajian agama secara empiris dapat diarahkan ke dalam dua aspek, yaitu manusia dan budaya. Pada dasarnya, agama diciptakan untuk membantu manusia agar dapat memenuhi keinginan-keinginan kemanusiaannya, dan sekaligus mengarahkan kepada kehidupan yang lebih baik. Hal ini jelas menunjukkan bahwa persoalan agama yang harus diamati secara empiris adalah tentang manusia. Tanpa memahami manusia, maka pemahaman tentang agama tidak akan menjadi sempurna.

Kedua, sebagai akibat dari pentingnya kajian manusia, maka mengkaji budaya dan masyarakat yang melingkupi kehidupan manusia juga menjadi sangat penting. Kebudayaan, sebagai system of meaning yang memberikan arti bagi kehidupan dan perilaku manusia, adalah aspek esensial manusia yang tidak dapat dipisahkan dalam memahami manusia. Mengutip Weber bahwa manusia adalah makhluk yang terjebak dalam jaring-jaring (web) kepentingan yang mereka buat sendiri, maka budaya adalah jaring-jaring itu. Geertz kemudian mengelaborasi pengertian kebudayaan sebagai pola makna (pattern of meaning) yang diwariskan secara historis dan tersimpan dalam simbol-simbol yang dengan itu manusia kemudian berkomunikasi, berperilaku dan memandang kehidupan. Oleh karena itu, analisis tentang kebudayaan dan manusia dalam tradisi antropologi tidaklah berupaya menemukan hukum-hukum seperti di ilmu-ilmu alam, melainkan kajian interpretatif untuk mencari makna (meaning).

Dipandang dari makna kebudayaan yang demikian, maka agama sebagai sebuah sistem makna yang tersimpan dalam simbol-simbol suci sesungguhnya adalah pola makna yang diwarisi manusia sebagai ethos dan juga worldviewnya. Geertz mengartikan ethos sebagai "tone, karakter dan kualitas dari kehidupan manusia yang berarti juga aspek moral maupun estetika mereka.” Bagi Geertz, agama telah memberikan karakter yang khusus bagi manusia yang kemudian memengaruhi tingkah laku kesehariannya. Di samping itu, agama memberikan gambaran tentang realitas yang hendak dicapai oleh manusia. 
Berdasar pada pengertian ini, agama sebagai ethos telah membentuk karakter yang khusus bagi manusia, yang kemudian dia bisa memenuhi gambaran realitas kehidupan (worldview) yang hendak dicapai oleh manusia.

Kajian antropologi juga memberikan fasilitas bagi kajian Islam untuk lebih melihat keragamaan pengaruh budaya dalam praktik Islam. Pemahaman realitas nyata dalam sebuah masyarakat akan menemukan suatu kajian Islam yang lebih empiris. Kajian agama dengan cross-culture akan memberikan gambaran yang variatif tentang hubungan agama dan budaya. Dengan pemahaman yang luas akan budaya-budaya yang ada, memungkinkan masyarakat untuk melakukan dialog, dan barangkali tidak mustahil memunculkan satu gagasan moral dunia.

\section{Tradisi dalam Kajian Agama}

Walaupun sejak awal disadari bahwa kajian tentang agama akan mengalami kesulitan karena meneliti sesuatu yang menyangkut kepercayaan (beliefs) yang ukuran kebenarannya terletak pada keyakinan, tradisi antropologi untuk mengkaji agama-terutama abad ke-16 dan ke-17-berkembang dengan pesat. Pritchard, salah seorang pionir dalam tradisi antropologi sosial di Inggris, mengatakan bahwa dilema kajian tentang agama adalah pemahaman realitas agama tidak akan sepenuhnya dapat dipahami, kecuali oleh orang yang mengamalkan agama itu sendiri. Hal ini pernah ia rasakan, misalnya, ketika menulis tentang perjuangan para Sufi di Cyrenica Libya melawan penjajahan Italia, ia merasa kesulitan untuk menjelaskan fenomena ketaatan pengikut Sufi kepada guru Sufi mereka. Tak dapat disangkal bahwa kemudian Pritchard dapat menggambarkan fenomena Sufi di Cyrenica dengan penuh empati (Ma'ruf, 2010: 5).

Kesulitan mempelajari agama dengan pendekatan budaya, dengan mempelajari wacana, pemahaman dan tingkah laku manusia dalam hubungannya dengan ajaran agama, dirasakan juga oleh mereka yang beragama. Kesulitan itu terjadi karena ketakutan untuk membicarakan masalah agama yang sakral dan bahkan mungkin tabu untuk dipelajari. Persoalan itu ditambah lagi dengan keyakinan bahwa agama adalah bukan hasil rekayasa intelektual manusia, tetapi berasal dari wahyu suci Tuhan sehingga realitas keagamaan diyakini sebagai sebuah "takdir sosial" yang tak perlu lagi dipahami.

Namun, sesungguhnya, harus disadari bahwa tanpa pengaruh budayaolah pikir manusia - agama tidak akan dapat berkembang. Bukankah penyebaran agama sangat terkait dengan usaha manusia untuk menyebarkannya ke wilayah-wilayah lain? Bukankah pula usaha-usaha manusia, jika dalam Islam bisa dilihat peran para sahabat, menerjemahkan dan mengkonstruksi ajaran 
agama ke dalam suatu kerangka sistem yang dapat diikuti oleh manusia? Lahirnya Ilmu Tafsir, Ilmu Hadis, Ilmu Fikih, dan Ilmu Usul Fikih adalah hasil konstruksi intelektual manusia dalam menerjemahkan ajaran agama sesuai dengan kebutuhan manusia di dalam lingkungan sosial dan budayanya. Keberagaman sosial budaya yang ada di dunia ini mengakibatkan pada kompleksitas agama.

Sebagai fenomena universal yang kompleks, keberadaan agama dalam masyarakat telah mendorong lahirnya banyak kajian tentang agama. Kajiankajian tentang agama berkembang bukannya karena agama ternyata tak dapat dipisahkan dari realitas sosial, tetapi ternyata realitas keagamaan berperan besar dalam perubahan sosial dan transformasi sosial. Kajian-kajian agama, baik dalam masyarakat primitif sampai pada masyarakat yang modern menunjukkan bahwa keberadaan agama selalu mengandung dua sisi yang berbarengan, yaitu kecenderungan transendensi dan sekularisasi.

Secara garis besar, kajian agama dalam antropologi dapat dikategorikan ke dalam empat kerangka teoritis; intellectualist, structuralist, functionalist, dan symbolist (Ma'ruf, 2010: 6). Tradisi kajian agama dalam antropologi diawali dengan mengkaji agama dari sudut pandang intelektualisme yang mencoba melihat definisi agama dalam setiap masyarakat dan kemudian melihat perkembangan (religious development) dalam satu masyarakat. Termasuk dalam tradisi ini misalnya Taylor yang berupaya mendefinisikan agama sebagai kepercayaan terhadap adanya kekuatan supranatural. Definisi agama ini sangat minimalis dan menunjukkan kecenderungan melakukan generalisasi realitas agama dari animisme sampai kepada agama monoteis. Oleh karenanya, kecenderungan tradisi intelektualisme ini kemudian meneliti dari sudut perkembangan agama dari yang animisme menuju monoteisme. Menurut Eliade, perkembangan agama menujukkan adanya gejala seperti bandul jam yang selalu bergerak dari satu ujung ke ujung yang lain. Demikian juga agama berkembang dari kecenderungan anismisme menuju monoteisme dan akan kembali ke animisme. Berdasar pada ajaran yang terdapat dalam kitab suci, Muller berpandangan bahwa agama bermula dari monoteisme kemudian berkembang menjadi agama-agama yang banyak itu (Ma'ruf, 2010: 6).

Ketiga teori, strukturalis, fungsionalis dan simbolis, sesungguhnya lahir dari Durkheim. Buku Durkheim, The Elementary Forms of the Religious Life, telah mengilhami banyak orang dalam melihat agama. Lewat buku itu, Durkheim ingin melihat agama dari bentuknya yang paling sederhana yang diimani oleh suku Aborigin di Australia sampai ke agama yang well-structured dan well- 
organised seperti yang dicerminkan dalam agama monoteis. Durkheim menemukan bahwa aspek terpenting dalam pengertian agama adalah adanya distingsi antara yang sacred dan yang profan. Namun demikian, ia tak setuju dengan pendapat yang menyatakan bahwa yang sacred itu selalu bersifat spiritual. Dalam agama sederhana suku Aborigin Australia ditemukan bahwa penyembahan kepada yang sacred ternyata diberikan kepada hal-hal yang profan semisal Kanguru (Durkheim, 2003: 200).

Di samping kritik terhadap pendekatan intelektualis itu, Durkheim juga mengungkapkan bahwa masyarakat dikonseptualisasikan sebagai sebuah totalitas yang diikat oleh hubungan sosial. Dalam pengertian ini, society (masyarakat) bagi Durkheim (2003: 200) adalah struktur dari ikatan sosial yang dikuatkan dengan konsensus moral. Pandangan ini yang mengilhami para antropolog untuk menggunakan pendekatan struktural dalam memahami agama dalam masyarakat. Levi-Strauss adalah satu murid Durkheim yang terus mengembangkan pendekatan strukturalisme, utamanya untuk mencari jawaban hubungan antara individu dan masyarakat. Bagi Levi-Strauss, agama, baik dalam bentuk mitos atau magic adalah model bagi kerangka bertindak bagi individu dalam masyarakat. Pandangan sosial Durkheim dikembangkan oleh Levi-Strauss kepada tidak saja secara hubungan sosial tetapi juga dalam ideologi dan pikiran sebagai struktur sosial (Maruf, 2010: 7).

Sementara itu, pandangan Durkheim tentang fungsi dalam masyarakat sangat berpengaruh dalam tradisi antropologi sosial di Inggris. Pandangan Durkheim yang mengasumsikan bahwa masyarakat selalu dalam keadaan equilibrium dan saling terikat satu dengan yang lain, telah mendorong para antropolog untuk melihat fungsi agama dalam masyarakat yang seimbang tersebut. Fungsi psikologi agama, sebagai penguat dari ikatan moral masyarakat dan fungsi sosial agama sebagai penguat solidaritas manusia menjadi dasar dari perkembangan teori fungsionalisme. Malinowski mengatakan bahwa fungsi agama dalam masyarakat adalah memberikan jawaban-jawaban terhadap permasalahan-permasalahan yang tidak dapat diselesaikan dengan common sense-rasionalitas dan kemampuan menggunakan teknologi. Dalam setiap kali menyelesaikan persoalan-persoalannya, manusia menggunakan kemampuan rasionalitas dan penciptaan teknologi. Ketika sebuah masyarakat traditional Suku Trobiand di daerah pesisir Papua Nugini menemukan bahwa ladangnya telah dirusak oleh babi hutan, maka dengan kemampuan rasionalitas dan penguasaan teknologinya masyarakat suku Trobiand membuat pagar agar babi tak dapat lagi masuk ke ladangnya. Namun, ketika hendak berburu ikan di lautan, dengan gelombang lautan dan cuaca yang tidak dapat mereka kontrol 
dengan kemampuan rasionalitas dan teknologi, mereka menggunakan agama sebagai pemecahnya. Sebelum mereka berlayar, mereka melakukan ritual dengan sesaji sebagai sarana komunikasi dengan kekuatan spiritual untuk menyelesaikan masalah yang unpredictable.

Teori simbolisme yang menjadi teori dominan pada dekade 70 -an sebenarnya juga mengambil akarnya dari Durkheim, walaupun tidak secara eksplisit Durkheim membangun teori simbolisme. Pandangan Durkheim mengenai makna dan fungsi ritual dalam masyarakat sebagai suatu aktivitas untuk mengembalikan kesatuan masyarakat mengilhami para antropolog untuk menerapkan pandangan ritual sebagai simbol. Salah satu yang menggunakan teori tersebut adalah Turner ketika ia melakukan kajian ritual (upacara keagamaan) di masyarakat Ndembu di Afrika. Turner melihat bahwa ritual adalah simbol yang dipakai oleh masyarakat Ndembu untuk menyampaikan konsep kebersamaan. Ritual bagi masyarakat Ndembu adalah tempat mentransendensikan konflik keseharian kepada nilai-nilai spiritual agama. Oleh karena itu, ritual, utama cult ritual (ritual yang berhubungan dengan masalah-masalah ketidakberunt ungan-misfortune) mengandung empat fungsi sosial yang penting. Pertama, ritual sebagai media untuk mengurangi permusuhan (reduce hostility) di antara warga masyarakat yang disebabkan adanya kecurigaankecurigaan niat jahat seseorang kepada yang lain. Kedua, ritual digunakan untuk menutup jurang perbedaan yang disebabkan friksi di dalam masyarakat. Ketiga, ritual sebagai sarana untuk memantapkan kembali hubungan yang akrab. Keempat, ritual sebagai medium untuk menegaskan kembali nilai-nilai masyarakat. Dengan demikian, Turner melihat ritual tidak hanya sebagai kewajiban (prescribed) saja, melainkan sebagai simbol dari apa yang sebenarnya terjadi dalam masyarakat.

Di samping tradisi intelektual dan tiga tradisi-strukturalis, fungsionalis dan simbolis-yang berakar dari tradisi Durkheim, ada tradisi dalam kajian agama yang berkembang dari pandangan-pandangan Weber. Tidak seperti halnya tradisi-tradisi intelektualis dan tradisi Durkheimian, Weber lebih tertarik untuk melihat hubungan antara doktrin agama dan aktivitas duniawi manusia, seperti misalnya ekonomi dan politik. Oleh karena itu, Weber tidak tertarik untuk mendiskusikan definisi atau argumentasi rasionalitas keberadaan agama. Dalam kajian tentang hubungan antara etika Protestan, khususnya sekte Calvinisme, dan perkembangan kapitalisme modern, menunjukkan minat Weber untuk mendiskusikan hubungan antara religious ethic dan kapitalisme. Ajaran etika tentang bekerja keras yang selalu muncul dalam tulisan-tulisan pendeta sekte 
Calvinisme dan yang juga menjadi tema-tema yang diulang-ulang dalam ceramah keagamaan sekte ini adalah sesuai dengan karakter buruh modern.

Tradisi yang dikembangkan oleh Weber ini banyak diikuti oleh ilmuwan sosial utamanya di Amerika. Kajian yang dilakukan oleh Bellah tentang Tokugawa Religion yang mencoba melihat hubungan etika agama dengan restorasi Meiji, dan juga kajian yang dilakukan oleh Geertz tentang pasar di Jawa dan priyayi Bali memakai pendekatan yang dipakai oleh Weber. Kajian-kajian yang demikian ini tidak lagi mempersoalkan benar dan salahnya suatu agama, tetapi melihat sejauhmana agama-aspek idealisme-memengaruhi perilaku sosial manusia.

Akibat yang nyata dari pendekatan kajian di atas menempatkan agama pada realitas empiris yang dapat dilihat dan diteliti. Dalam pandangan ilmu sosial, pertanyaan keabsahan suatu agama tidak terletak pada argumentasiargumentasi teologisnya, melainkan terletak pada bagaimana agama dapat berperan dalam kehidupan sosial manusia. Dalam hal ini, agama diposisikan dalam kerangka sosial empiris, sebagaimana realitas sosial lainnya. Hal ini karena dalam kaitannya dengan kehidupan manusia, tentu hal-hal yang empirislah-walaupun hal yang gaib juga menjadi hal penting-yang menjadi perhatian kajian sosial.

Jika agama diperuntukkan untuk kepentingan manusia, maka sesungguhnya persoalan-persoalan manusia juga merupakan persoalan agama. Dalam Islam manusia digambarkan sebagai khalifah (wakil) Tuhan di muka bumi. Secara antropologis, ungkapan ini berarti bahwa sesungguhnya realitas manusia adalah realitas ketuhanan. Tanpa memahami realitas manusia-termasuk di dalamnya adalah realitas sosial budayanya — pemahaman terhadap ketuhanan tidak akan sempurna karena separuh dari realitas ketuhanan tidak dimengerti. Di sini terlihat betapa kajian tentang manusia, yang menjadi pusat perhatian antropologi, menjadi sangat penting.

Pentingnya mempelajari realitas manusia ini juga terlihat dari pesan alQur'an ketika membicarakan konsep-konsep keagamaan. Al-Qur'an seringkali menggunakan "orang” untuk menjelaskan konsep kesalehan. Misalnya, untuk menjelaskan tentang konsep takwa, al-Qur'an menunjuk pada konsep "muttaqīn”, untuk menjelaskan konsep sabar, al-Qur'an menggunakan kata “orang sabar" dan seterusnya. Kalau merujuk pada pesan al-Qur'an yang demikian itu sesungguhnya, konsep-konsep keagamaan itu termanifestasikan dalam perilaku manusia. Oleh karena itu, pemahaman konsep agama terletak pada pemahaman realitas kemanusiaan. 
Dengan demikian, realitas manusia sesungguhnya adalah realitas empiris dari ketuhanan. Persoalan-persoalan yang dihadapi manusia adalah cerminan dari permasalahan ketuhanan. Dengan demikian, mempelajari realitas manusia, dengan segala aspeknya, adalah mempelajari Tuhan—baca agama—dalam realitas empiris. Kenyataan bahwa realitas manusia-yang tercermin dalam bermacam-macam budaya - beragam, maka diperlukan kajian cross culture untuk melihat realitas universal agama. Hodgson menggambarkan bahwa bermacam-macamnya manifestasi agama dalam kebudayaan tertentu-little tradition — sesungguhnya adalah mosaik dari realitas universal agama—great tradition.

\section{Agama sebagai Sistem Budaya}

Pada beberapa antropolog, terdapat konsep yang menyatakan bahwa agama adalah bagian dari kebudayaan. Dengan demikian, kebudayaan mencakup di dalamnya agama. Di pihak lain, ada pula yang berpendapat bahwa kebudayaan adalah bagian dari agama. Dengan demikian, agama mencakup di dalamnya kebudayaan (Bukhori, 2005: 114). Pernyataan di atas dapat dimaklumi jika yang dimaksudkan itu adalah pengamalan umat terhadap agamanya, dan bukan agamanya itu sendiri. Apabila agama disebutkan sebagai bagian dari kebudayaan, maka jelas di dalamnya ada campur tangan manusia. Adapun agama Islam adalah agama yang berisi ajaran-ajaran Allah yang suci terbebas dari sentuhan tangan manusia (Bukhori, 2005: 114).

Agama kalau dikatakan bagian dari kebudayaan bukan ditujukan kepada muatan agama itu sendiri, melainkan corak pengamalan atau ekspresi religius pemeluk agama itu terhadap ajaran agamanya. Atau dalam bahasa yang berbeda, menurut Suparlan, pada waktu agama dilihat dan diperlakukan sebagai kebudayaan, maka yang dilihat adalah agama sebagai keyakinan yang ada dan hidup dalam masyarakat manusia dan bukan agama yang terwujud sebagai petunjuk-pet unjuk, larangan-larangan, dan perintah-perintah Tuhan yang ada dalam al-Qur'an dan hadis Nabi (Suparlan, 1995: 114). Jika agama Islam yang tertuang dalam teks suci dalam al-Qur'an dan hadis itu bersifat universal, maka keyakinan keagamaan yang hidup dalam masyarakat itu bersifat lokal, yaitu yang sesuai dengan kondisi masyarakat, sejarah, lingkungan hidup, dan kebudayaannya.

Geertz adalah orang pertama yang mengungkapkan pandangan tentang agama sebagai sebuah sistem budaya. Karya Geertz, "Religion as a Cultural System," dianggap sebagai tulisan klasik tentang agama. Pandangan Geertz, saat itu ketika teori-teori tentang kajian agama mandek pada teori-teori besar 
Marx, Weber, dan Durkheim yang berkut at pada teori fungsionalisme dan struktural fungsionalisme, memberikan arah baru bagi kajian agama. Geertz mengungkapkan bahwa agama harus dilihat sebagai suatu sistem yang mampu mengubah suatu tatanan masyarakat. Tidak seperti pendahulunya yang menganggap agama sebagai bagian kecil dari sistem budaya, Geertz berkeyakinan bahwa agama adalah sistem budaya sendiri yang dapat membentuk karakter masyarakat. Walaupun Geertz mengakui bahwa ide yang demikian tidaklah baru, tetapi agaknya sedikit orang yang berusaha untuk membahasnya lebih mendalam. Oleh karena itu, Geertz mendefinisikan agama sebagai:

"A system of symbols which acts to establish powerful, pervasive and longlasting moods and motivations of a general order of existence and clothing these conceptions with such an aura of factuality that the moods and motivations seem uniquely realistic."

Dengan pandangan seperti ini, Geertz dapat dikategorikan ke dalam kelompok kajian semiotic tradition warisan dari de Saussure yang pertama mengungkapkan tentang makna simbol dalam tradisi linguistik. Geertz mengartikan simbol sebagai suatu kendaraan (vehicle) untuk menyampaikan suatu konsepsi tertent u. Bagi Geertz, norma atau nilai keagamaan harusnya diinterpretasikan sebagai sebuah simbol yang menyimpan konsepsi tertentu.

Simbol keagamaan tersebut mempunyai dua corak yang berbeda; pada satu sisi ia merupakan modes for reality, dan di sisi yang lainnya ia merupakan modes of reality. Yang pertama, modes for reality, menunjukkan suatu eksistensi agama sebagai suatu sistem yang dapat membentuk masyarakat ke dalam cosmic order tertentu. Sementara itu, sisi modes of reality merupakan pengakuan Geertz akan sisi agama yang dipengaruhi oleh lingkungan sosial dan perilaku manusia.

Geertz menerapkan pandangan-pandangannya untuk meneliti tentang agama dalam satu masyarakat. Karya Geertz yang tertuang dalam The Religion of Java maupun Islam Observed merupakan dua buku yang bercerita bagaimana agama dikaji dalam masyarakat. Buku The Religion of Java memperlihatkan hubungan agama dengan ekonomi dan politik suatu daerah. Agama menjadi ideologi kelompok yang kemudian menimbulkan konflik maupun integrasi dalam suatu masyarakat.

Sementara itu, Islam Observed ingin melihat perwujudan agama dalam masyarakat yang berbeda untuk memperlihatkan kemampuan agama dalam mewujudkan masyarakat maupun sebagai perwujudan dari interaksi dengan budaya lokal. 


\section{E. Simpulan}

Kajian-kajian tentang agama dan budaya dapat diarahkan dalam berbagai kerangka. Pertama dapat diterapkan dalam upaya mencari konsep-konsep lokal tentang bagaimana agama dan budaya berinteraksi. Kedua, kajian tersebut dapat dipusatkan untuk memetakan Islam lokal dalam sebuah peta besar Islam universal. Ketiga, local discourse atau local knowledge yang tumbuh dari pergumulan agama dan budaya dapat dijadikan sebagai tambahan wacana baru globalisasi. Kajian tentang local Islam dapat dijadikan sebagai pengkayaan wacana manusia. Pemahaman agama secara keseluruhan tidak akan tercapai tanpa memahami separuh dari agama, yaitu manusia. Barangkali tidak berlebihan untuk menyebut bahwa realitas manusia sesungguhnya adalah realitas ketuhanan yang empiris. Di sinilah letak pentingnya kajian antropologi dalam mengkaji Islam. Sebagai ilmu yang mengkhususkan diri mempelajari manusiayang merupakan realitas empiris agama - maka antropologi juga merupakan separuh dari ilmu agama itu sendiri.

\section{Daftar Pustaka}

Bukhori, Didin Saefuddin. 2005. Metodologi Studi Islam. Bogor: Granada. Durkheim, Emile. 2003. Sejarah Agama (The Elementary Forms of the Religious Life), diterj. oleh Inyiak Ridwan Munir. Yogyakarta: IRCiSoD.

Geertz, Clifford. 1981. Abangan Santri Priyayi dalam Masyarakat Jawa, diterj. oleh Aswab Mahasin. Jakarta: Pustaka Jaya.

1982. Islam yang Saya Amati: Perkembangan di Maroko dan Indonesia, diterj. oleh Hasan Basari. Jakarta: Yayasan Ilmu-ilmu Sosial. Gellner, David N. 2009. "Pendekatan Antropologis", dalam Peter Connolly, (Ed.), Aneka Pendekatan Studi Agama, terj. Imam Khoiri. Yogyakarta: LKiS.

Ma'ruf, Jamhari. 2009. "Pendekatan Antropologi dalam Kajian Islam" dalam http://www.ditpertais.net, diakses pada 30 September 2010.

Pranowo, Bambang M. 2009. Memahami Islam Jawa. Jakarta: Pustaka Alvabet. Rakhmat, Jalaluddin. 2004. Madrasah Ruhaniah. Bandung: Muthahhari Press. Suparlan, Parsudi. 1995. The Javanese in Surinam: Ethnicity in an Ethnically Plural Society. Arizona: Arizona State University. 1995. "Kata Pengantar", dalam Roland Robertson (Ed.). Agama dalam Analisa dan Interpretasi Sosiologis. Jakarta: Raja Grafindo Persada. 
Muhamad Taufik Hidayat: Antropologi Islam di Indonesia (hal. 31-45)

1998. "Penelitian Agama Islam: Tinjauan Disiplin Antropologi”, dalam Mastuhu dan M. Deden Ridwan (Ed.). Tradisi Baru Penelitian Agama Islam: Tinjauan Antar-Disiplin Ilmu Agama. Bandung: Nuansa.

Woodward, Mark R. 1999. Islam Jawa: Kesalehan Normatif versus Kebatinan diterj. oleh Hairus Salim HS. Yogyakarta: LKiS. 